\title{
Efeito da Monensina e Extrato de Própolis sobre a Produção de Amônia e Degradabilidade In Vitro da Proteína Bruta de Diferentes Fontes de Nitrogênio
}

\author{
Juliana Silva Oliveira1, Rogério de Paula Lana², Arnaldo Chaer Borges ${ }^{3}$, Augusto César \\ de Queiroz ${ }^{2}$, Ivan Carlos C. Almeida ${ }^{4}$
}

\begin{abstract}
RESUMO - Este experimento foi conduzido com o objetivo de avaliar a fermentação da proteína de três fontes de nitrogênio (tripticase, farelo de soja e farinha de peixe), com ou sem monensina ou extrato de própolis. Foram feitas incubações utilizando 7,2 mL de tampão de McDougall, 2,0 mL de inóculo, 0,2 mL de solução etanólica contendo ou não monensina ou própolis e 84,4, 150 ou $112,5 \mathrm{mg} / 10 \mathrm{~mL}$ de tripticase, farelo de soja e farinha de peixe, respectivamente, em arranjo fatorial $3 \times 3$. Os frascos foram incubados anaerobicamente a $39^{\circ} \mathrm{C}$ em banho-maria durante 120 horas, coletando-se amostras do meio ao longo do tempo de incubação para determinação de amônia, proteína microbiana, proteína solúvel e degradabilidade da proteína. A farinha de peixe causou menor produção de amônia que a tripticase e o farelo de soja no tratamento controle, devido à sua menor degradabilidade. Tanto a monensina como a própolis reduziram a produção de amônia nos tratamentos contendo tripticase e farelo de soja, induzindo ao acúmulo de proteína solúvel no meio de incubação. A síntese de proteína microbiana foi similar para os três alimentos, com presença ou não dos inibidores, exceto no caso da própolis que a estimulou no tratamento contendo farinha de peixe. Observou-se maior degradabilidade da proteína bruta nos tratamentos controle para o farelo de soja (73\%), em relação à farinha de peixe (42\%). A monensina reduziu a degradação da tripticase e do farelo de soja, pela inibição da produção de amônia, e a própolis aumentou a degradação da farinha de peixe, pelo aumento da concentração de proteína solúvel no meio. Devido ao efeito in vitro da própolis sobre a atividade de fermentação, há necessidade de realização de pesquisas para verificar o efeito da mesma sobre a fermentação ruminal e sobre o desempenho dos animais.
\end{abstract}

Palavras-chave: alimentos, amônia, microrganismos, ionóforos, própolis, rúmen

\section{Effect of Monensin and Propolis Extract on Ammonia Production and in vitro Degradability of Crude Protein of Different Nitrogen Sources}

\begin{abstract}
This experiment had as objective to evaluate protein fermentation of three nitrogen sources (trypticase, soybean meal and fish meal), with or without monensin or propolis extract addition. Incubations were done by using $7.2 \mathrm{~mL}$ of McDougall buffer, $2.0 \mathrm{~mL}$ of inocula, $0.2 \mathrm{~mL}$ of ethanolic solution with or without monensin or propolis and $84.4,150$ or $112.5 \mathrm{mg} / 10 \mathrm{~mL}$ of trypticase, soybean meal and fish meal, respectively, in a $3 \times 3$ factorial arranjement. The flasks were incubated anaerobically at $39^{\circ} \mathrm{C}$ in water bath during 120 hours, and samples were collected from the media over time for ammonia, microbial protein, soluble protein and protein degradability determinations. Fish meal caused lesser ammonia production than trypticase and soybean meal in control treatment, due to its lower degradability. Monensin and propolis decreased ammonia production in the trypticase and soybean meal treatments, leading to accumulation of soluble protein in the media. The microbial protein synthesis was similar among the three feed sources and with presence or absence of inhibitors, except in the case of propolis that estimulated synthesis in the fish meal treatment. There was greater protein degradability of the control treatment for soybean meal (73\%) than fish meal (42\%). Monensin reduced degradation of trypticase and soybean meal, by inhibiting ammonia production, and propolis increased degradation of fish meal, by increasing soluble protein concentration in the media. Due to the in vitro effect of propolis on fermentation activity, it is necessary to carry out researches in order to verify its effect on ruminal fermentation and animal performance.
\end{abstract}

Key Words: ammonia, feeds, ionophores, microorganisms, propolis, rumen

\section{Introdução}

Os microrganismos ruminais são de fundamental importância para os animais ruminantes, pela trans- formação dos carboidratos estruturais, principais constituintes das gramíneas, em ácidos graxos voláteis, que são fontes de energia disponíveis para absorção pelo sistema digestivo. Os microrganismos ruminais

${ }^{1}$ Estudante de graduação - Departamento de Zootecnia - UFV - 36.571-000 - Viçosa - MG. Bolsista da FAPEMIG.

2 Professor do Departamento de Zootecnia - UFV - 36.571-000 - Viçosa - MG; Bolsista do CNPq. Autor para correspondências. (rlana@ufv.br; aqueiroz@ufv.br)

3 Professor do Departamento de Microbiologia - UFV - 36.571-000 - Viçosa - MG; Bolsista do CNPq (chaer@ufv.br)

${ }^{4}$ Estudante de graduação - Departamento de Zootecnia - UFV - 36.571-000 - Viçosa - MG. Bolsista do CNPq. 
contribuem ainda com o suprimento de proteínas e vitaminas aos animais, após a digestão e absorção das mesmas no intestino delgado. Daí, a importância de se saber cada vez mais sobre a sua atividade dentro do rúmen.

As bactérias celulolíticas têm como principal fonte de nitrogênio $(\mathrm{N})$ a amônia, que resulta do processo fermentativo da proteína. No entanto, quando a concentração de amônia está em excesso no fluido ruminal, essa não é utilizada eficientemente para a síntese microbiana (Satter \& Slyter, 1974), o que resultará no aumento da excreção de $\mathrm{N}$, aumentando o custo energético de produção de uréia (Russell et al., 1992). Além disso, o excesso de amônia será excretado via urina, podendo contaminar solos e cursos d'água (Yeck et al., 1975; Nolan et al., 1976).

Os intermediários da produção de amônia são os aminoácidos e peptídeos, que são provenientes da quebra da proteína solúvel do alimento através de enzimas microbianas ruminais, sendo os mesmos incorporados à proteína microbiana ou desaminados. Porém, ao se ter quebra excessiva de peptídeos, os mesmos não são assimilados totalmente, ocorrendo perda desses na forma de amônia. Uma forma de reduzir essa perda de nitrogênio pelo animal seria com a administração dos inibidores bacterianos, como monensina e própolis (Barbosa et al., 2001; Stradiotti Jr. et al., 2001).

O ionóforo monensina é um antibiótico que diminui o crescimento de bactérias proteolíticas (Hino \& Russell, 1986) e a degradação de proteína hidrolisada e dietética (Russell \& Martin, 1984). A monensina inibe principalmente bactérias gram-positivas, já que a resistência ao ionóforo está relacionada à presença de uma camada de natureza lipopolissacarídica, externa à membrana celular, existentes em bactérias gram-negativas. Apesar de a monensina ter pouco impacto na média de ganho diário do animal, ela contribui na diminuição da ingestão de alimento e na taxa acetato/proprionato no fluido ruminal (Russell, 1996). A monensina é fornecida em dietas para animais que consomem grande quantidade de grãos, em que pequena economia na hora da aquisição dos alimentos, para os grandes produtores de carne ou leite, se torna importante.

A própolis, resina proveniente de substâncias coletadas das plantas e misturadas com secreções de abelhas, tem demonstrado importantes propriedades terapêuticas, como atividade antimicrobiana, antiinflamatória e cicratizante (Ghisalberti, 1979).
Estudos têm demonstrado que a própolis atua sobre a inibição de bactérias gram-positivas, sendo esperado que sua adição em cultivo de microrganismos ruminais iniba o crescimento de bactérias proteolíticas da mesma forma que o ionóforo monensina.

Este experimento teve como objetivo avaliar a fermentação da proteína de três fontes de nitrogênio (tripticase, farelo de soja e farinha de peixe), com ou sem a adição dos compostos antimicrobianos monensina e própolis.

\section{Material e Métodos}

O experimento foi realizado no Laboratório de Microbiologia de Anaeróbios, Departamento de Microbiologia da Universidade Federal de Viçosa (UFV), Viçosa, Minas Gerais. Foi utilizado o líquido de rúmen de um bovino fistulado, mantido em pastagem de capim-Brachiaria. O animal foi alojado no Laboratório de Animais do Departamento de Zootecnia da UFV.

O líquido ruminal foi coletado pela manhã, com o $\mathrm{pH}$ em torno da neutralidade. O líquido foi filtrado em quatro camadas de gaze, acondicionado em garrafa térmica, com fechamento hermético, e transportado imediatamente ao laboratório, onde foi mantido em banho-maria a $39^{\circ} \mathrm{C}$. Após as partículas alimentares flutuarem e os protozoários sedimentarem, foi obtido o líquido da fase mediana do frasco, sendo esse utilizado como inóculo.

A solução tampão de McDougall, utilizada nas incubações, constituiu-se de 9,80 g de $\mathrm{NaHCO}_{3} ; 4,65 \mathrm{~g}$ de $\mathrm{Na}_{2} \mathrm{HPO}_{4} * 2 \mathrm{H}_{2} \mathrm{O} ; 0,57 \mathrm{~g}$ de $\mathrm{KCl} ; 0,12 \mathrm{~g}$ de $\mathrm{MgSO}_{4} * 7 \mathrm{H}_{2} \mathrm{O}$ e $0,04 \mathrm{~g}$ de $\mathrm{CaCL}_{2}$, diluídos com água destilada até o volume de $1000 \mathrm{~mL}$.

Foram testadas três fontes de nitrogênio (tripticase ou hidrolizado de caseína, farelo de soja e farinha de peixe), sem ou em combinação com o antibiótico monensina, puro para análise, ou em combinação com extrato de própolis, em arranjo fatorial $3 \times 3$. O extrato foi obtido utilizando $30 \mathrm{~g}$ de própolis moída em $100 \mathrm{ml}$ de solução alcoólica (70\% de álcool e 30\% de água) durante 10 dias, seguido de filtração em papel de filtro. Foi feita, então, diluição do extrato com etanol, na proporção de 1:1. As fontes de nitrogênio tripticase, farelo de soja e farinha de peixe continham, respectivamente, 78,3; 45,6 e 50,6\% de proteína bruta com base na matéria seca, determinadas pelo método Kjeldahl (Silva, 1990).

As incubações foram realizadas em frascos de 
vidro de $50 \mathrm{~mL}$, hermeticamente fechados, contendo 7,2 mL de tampão de McDougall; 2,0 mL de inóculo; contendo ou não $0,2 \mathrm{~mL}$ dos inibidores monensina ou própolis. A quantidade de monensina adicionada no meio de cultura possibilitou que a concentração final do meio atingisse o valor de 5,0 $\mu \mathrm{M}$, nível atingido in vivo pela recomendação de uso do produto comercial. Os alimentos foram adicionados de forma a terem as mesmas quantidades de proteína e carboidratos nos tratamentos. Assim, foram adicionados $150 \mathrm{mg}$ de farelo de soja; ou 112,5 mg de farinha de peixe mais $37,5 \mathrm{mg}$ de amido; ou $84,4 \mathrm{mg}$ de tripticase mais 65,6 mg de amido.

Os frascos foram saturados com gás dióxido de carbono e incubados à temperatura de $39^{\circ} \mathrm{C}$ em banho-maria, por 120 horas. Coletaram-se amostras de $0,6 \mathrm{~mL}$ do material incubado para determinação de amônia, proteína microbiana e proteína solúvel nos tempos $0,24,48,72,96$ e 120 horas, a partir do início das incubações. As alíquotas foram coletadas por meio de seringas, para que se mantivesse a anaerobiose dentro dos frascos.

As amostras foram centrifugadas em tubos eppendorf de $1,5 \mathrm{~mL}$ a $12.000 \mathrm{rpm}$, por 10 minutos, onde o sobrenadante foi transferido para um novo tubo eppendorf e congelado para posterior análise de amônia e proteína solúvel. Os peletes (sedimentos advindos da centrifugação) foram resuspensos em solução salina $(\mathrm{NaCl}, 0,9 \%)$ e centrifugados a 12.000 rpm, por 10 minutos, duas vezes consecutivas, sendo, por último, ressuspensos em água destilada até o volume de 0,6 mL. Após homogeneização, as amostras foram congeladas para posteriores análises de proteína microbiana. A análise de amônia foi feita pelo método colorimétrico de Chaney \& Marbarch (1962) e as análises de proteína solúvel e microbiana, pelo método de Lowry et al. (1951).

Para obter a curva de degradabilidade potencial da proteína (DP), determinou-se a cada 24 horas a proporção do nitrogênio solubilizado no meio de cultura ( $\mathrm{N}$-amônia, N-proteína solúvel e N-proteína microbiana), após descontar o nitrogênio presente originalmente no meio (N-LR $0 \mathrm{~h}$ ), em relação à quantidade total de nitrogênio do alimento incubado (N-alim). A fórmula utilizada no cálculo da degradabilidade potencial é apresentada a seguir:

$\mathrm{DP}(\%)=\frac{\left(\mathrm{N}-\mathrm{NH}_{3}+\mathrm{N} \text {-proteína solúvel }+\mathrm{N} \text {-proteína microbiana }\right)-(\mathrm{N}-\mathrm{LR} \text { Oh })}{(\mathrm{N}-\text { alim })} \times 100$

$\mathrm{O}$ experimento foi analisado em delineamento inteiramente casualizado em fatorial $3 \times 3$ (três alimentos; e ausência ou presença da monensina ou da própolis), com três repetições (três frascos de cultura). As análises estatísticas foram realizadas pelo procedimento ANOVA do pacote estatístico SAS (1996). O efeito dos alimentos ou sua interação com monensina ou própolis tiveram suas médias comparadas pelo teste de Tukey a $5 \%$ de probabilidade.

\section{Resultados e Discussão}

A produção de amônia por microrganismos ruminais atingiu valor máximo às 24 horas de fermentação no tratamento controle ao fermentar a tripticase (Figura 1) e às 48 horas ao fermentar o farelo de soja (Figura 2). A monensina e a própolis foram ambas eficientes na inibição da produção de amônia nas duas fontes de nitrogênio. $\mathrm{O}$ efeito da monensina em reduzir a produção de amônia foi verificado anteriormente in vitro (Russell et al., 1988; Chen \& Russell, 1989; Cunha, 1999) e in vivo (Yang \& Russell, 1993; Krause \& Russell, 1996). A capacidade da própolis em reduzir a produção de amônia pelos microrganismos ruminais confirma os primeiros resultados observados com uso da própolis in vitro e in vivo por Stradiotti Jr. et al. (2001).

A alta produção de amônia do tratamento controle está associada à menor concentração de proteína solúvel ao longo da incubação (Figuras 1 e 2). A concentração de proteína solúvel atingiu valores mínimos após 72 horas, coincidindo com a concentração máxima de proteína microbiana nos três tratamentos e a concentração de amônia nos tratamentos contendo inibidores microbianos.

Verifica-se nas Figuras 1 e 2 que os inibidores não afetaram o crescimento microbiano, mas foram capazes de inibir a produção de amônia, permitindo acúmulo de peptídeos e aminoácidos no meio. Esta observação apresenta implicação prática, pois o acúmulo de peptídeos e aminoácidos no rúmen favorece o maior fluxo dos mesmos para o intestino delgado, com menores perdas ruminais das proteínas por fermentação(Russell et al., 1988; Chen \& Russell, 1989).

A produção de amônia a partir da farinha de peixe foi bem inferior àquela verificada com a tripticase $\mathrm{e}$ o farelo de soja (Figura 3), devido à menor degradabilidade da sua proteína, e não houve redução da produção de amônia por ação dos inibidores. A concentração da proteína solúvel foi também inferior à observada com as outras duas fontes de nitrogênio, 
devido à menor solubilidade da proteína da farinha de peixe. Entretanto, nas três fontes de nitrogênio, sempre houve maior concentração de proteína solúvel ao início da incubação no tratamento contendo própolis. Este resultado demonstra que a própolis tem forte efeito inibidor da produção de amônia.

Uma vez que os parâmetros produção de amônia e proteína solúvel normalmente atingiram o platô entre 24 e 48 horas, como foi observado também por Barbosa
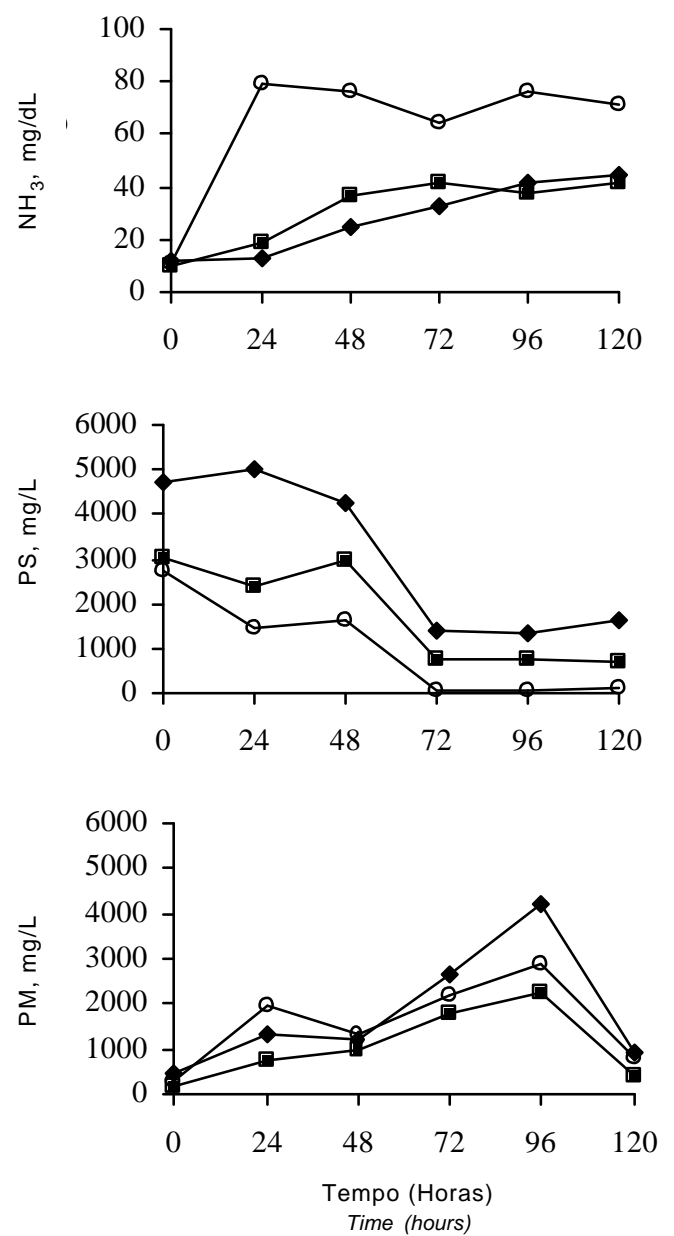

Figura 1 - Concentração de amônia, proteína solúvel (PS) e proteína microbiana (PM) ao longo do tempo de fermentação, por microrganismos ruminais, em meios de cultura contendo tripticase $(84,4 \mathrm{mg} / 10 \mathrm{~mL})$. As figuras acima apresentam dados referentes aos tratamentos controle (o), monensina (घ) e própolis ( ). Cada ponto corresponde à média de três observações.

Figure 1 - Concentration of ammonia, soluble protein (PS) and microbial protein (PM) over time during fermentation by ruminal microorganisms of media containing trypticase $(84.4 \mathrm{mg} / 10 \mathrm{~mL})$. The figures present data of the treatments control (o), monensin (-) and propolis ( ). Each point originated from the mean of three observations. et al. (2001), optou-se por realizar as análises estatísticas dos efeitos dos tratamentos às 48 horas de incubação (Tabela 1). Houve efeito de interação entre as fontes de nitrogênio e inibidores sobre a produção de amônia, proteína solúvel e proteína microbiana $(\mathrm{P}<0,05)$.

A farinha de peixe causou menor produção de amônia que a tripticase e o farelo de soja no tratamento controle $(\mathrm{P}<0,05)$, devido à menor degradabilidade de sua proteína. Este resultado está de acordo com
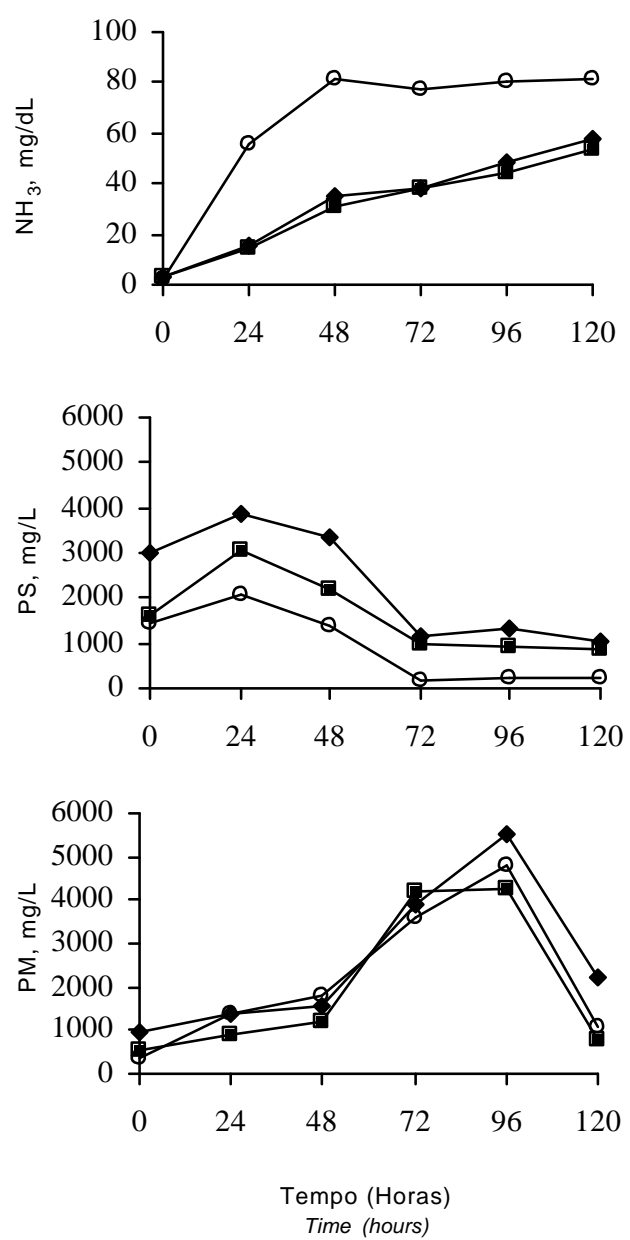

Figura 2 - Concentração de amônia, proteína solúvel (PS) e proteína microbiana (PM) ao longo do tempo de fermentação, por microrganismos ruminais, em meios de cultura contendo farelo de soja (150,0 mg/10 mL). As figuras acima apresentam dados referentes aos tratamentos controle (o), monensina ( $\mathbf{\square})$ e própolis $(\bullet)$. Cada ponto corresponde à média de três observações.

Figure 2 - Concentration of ammonia, soluble protein (PS) and microbial protein (PM) over time during fermentation by ruminal microorganisms of media containing soybean meal (150 $\mathrm{mg} / 10 \mathrm{~mL})$. The figures present data of the treatments control (o), monensin (घ) and propolis ( ). Each point originated from the mean of three observations. 
Tabela 1 - Efeito de fontes de nitrogênio e inibidores (monensina e própolis) sobre a concentração de amônia, proteína solúvel e proteína microbiana em meios de cultura, após 48 horas de fermentação por microrganismos ruminais

Table 1 - Effect of nitrogen sources and inhibitors (monensin and propolis) on ammonia concentration, soluble protein and microbial protein in culture media, after 48 hours of fermentation by ruminal microorganisms

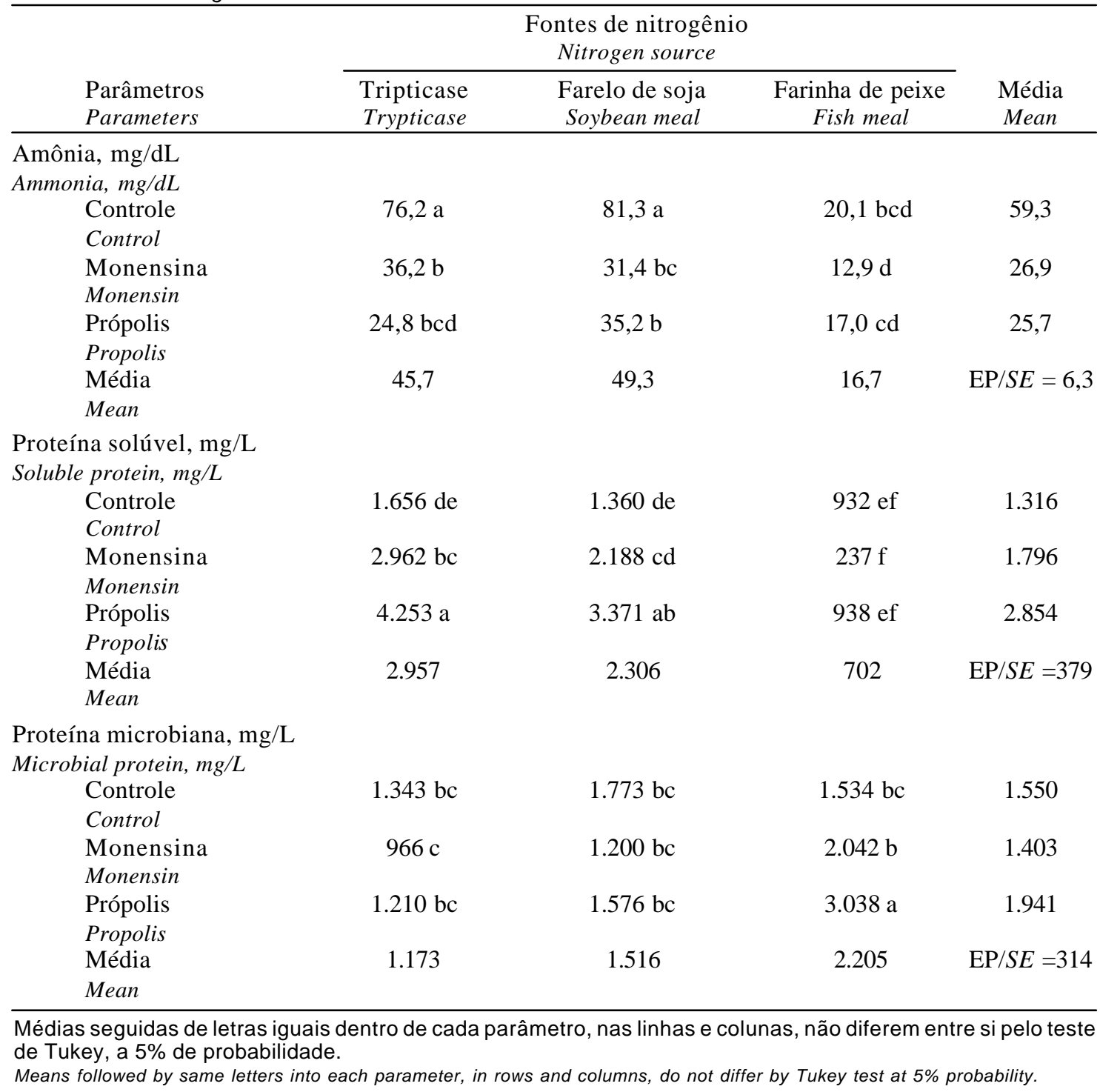

Cunha (1999) e Barbosa et al. (2001), que observaram correlação positiva entre produção de amônia e degradabilidade da proteína in vitro, ou seja, quanto maior a degradabilidade da proteína maior será a produção de amônia.

A monensina e própolis reduziram a produção de amônia nos tratamentos contendo tripticase e farelo de soja $(\mathrm{P}<0,05)$, mas não reduziram no tratamento contendo farinha de peixe, estando de acordo com Russell \& Strobel (1989) que afirmam que os ionóforos apresentam melhores resultados em dietas contendo alta relação proteína degradável/carboidrato fermentescível. A redução da produção de amônia ocorreu devido à inibição da população microbiana com alta capacidade de desaminação de aminoácidos (Russell et al., 1988; Chen \& Russell, 1989).

A concentração de proteína solúvel foi similar para os três alimentos no tratamento controle $(\mathrm{P}>0,05)$. Quando a tripticase, fonte de alta degradabilidade, foi utilizada, a própolis permitiu maior acúmulo de proteína solúvel que a monensina e esta em relação ao controle. No caso do farelo de soja, fonte de degradabilidade intermediária, somente a própolis permitiu acúmulo de proteína solúvel, ao passo que, quando a farinha de peixe foi utilizada, os inibidores não interferiram na concentração de proteína solúvel. 

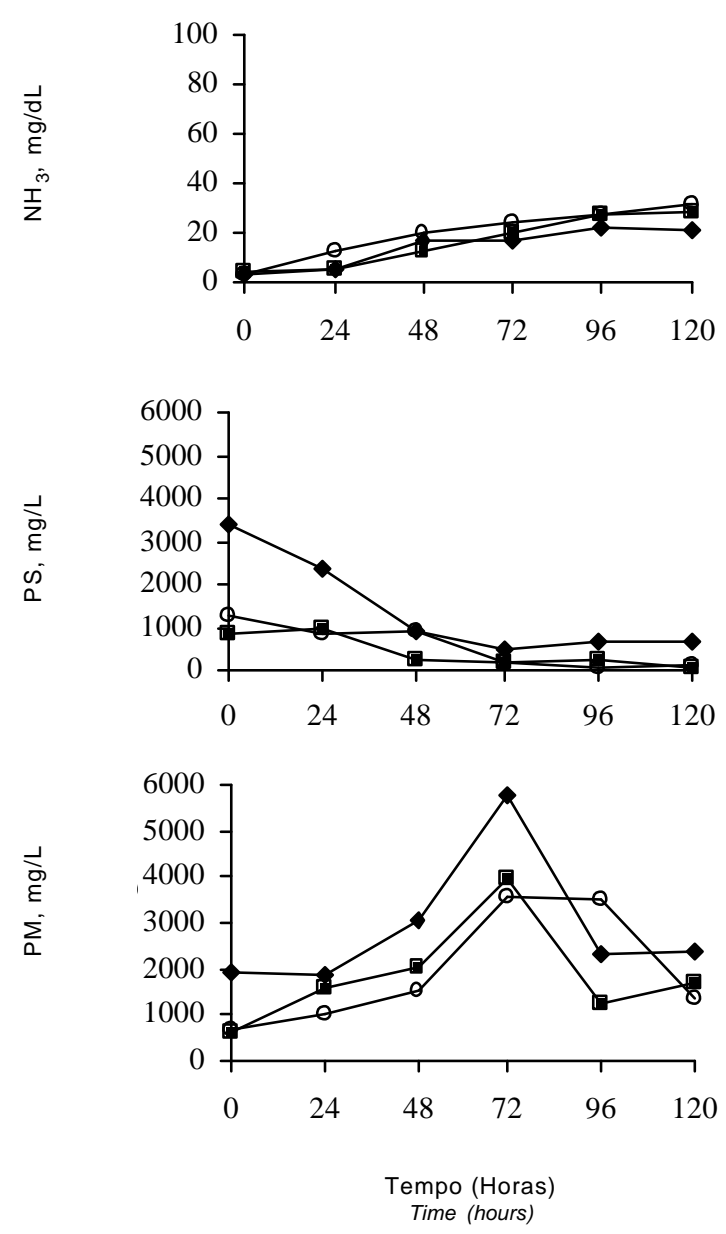

Figura 3 - Concentração de amônia, proteína solúvel (PS) e proteína microbiana (PM) ao longo do tempo de fermentação, por microrganismos ruminais, em meios de cultura contendo farinha de peixe $(112,5 \mathrm{mg} / 10 \mathrm{~mL})$. As figuras acima apresentam dados referentes aos tratamentos controle (o), monensina ( $\mathbf{0})$ e própolis $(\bullet)$. Cada ponto corresponde à média de três observações.

Figure 3 - Concentration of ammonia, soluble protein (PS) and microbial protein (PM) over time during fermentation by ruminal microorganisms of media containing fish meal $(112.5 \mathrm{mg} / 10 \mathrm{~mL})$. The figures present data of the treatments control (o), monensin ( $\mathbf{\square})$ and propolis $(\bullet)$. Each point originated from the mean of three observations.

A síntese de proteína microbiana também foi similar para os três alimentos no tratamento controle $(\mathrm{P}>0,05)$. Os inibidores, geralmente, não interferiram com o crescimento microbiano, exceto quando a própolis estava presente no tratamento contendo farinha de peixe, onde houve estímulo ao crescimento microbiano.

A Figura 4 apresenta a curva de degradação
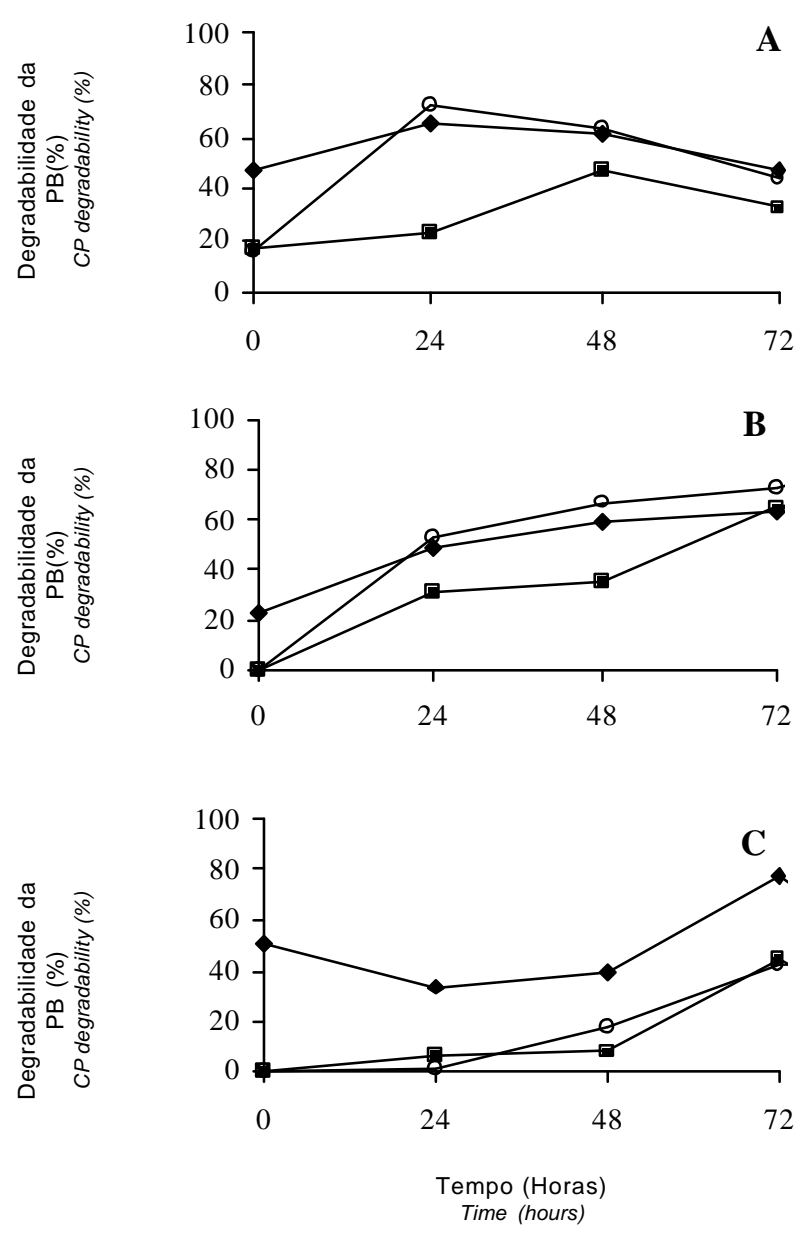

Figura 4 - Degradabilidade da proteína das fontes de nitrogênio (tripticase, $A$; farelo de soja, $B$; farinha de peixe, C), ao longo de 72 horas de incubação. As figuras acima apresentam dados referentes aos tratam entos controle (o), monensina ( $\mathbf{a})$ e própolis $(\bullet)$. Cada ponto corresponde à média de três observações.

Figure 4 - Protein degradability of nitrogen sources (trypticase, A; soybean meal, B; fish meal, C), over 72 hours of incubation. The figures present data of the treatments control (0), monensin (0) and propolis $(\bullet)$. Each point originated from the mean of three observations.

potencial da proteína bruta. Observa-se maior degradabilidade da proteína bruta nos tratamentos controle às 72 horas para o farelo de soja $(73 \%)$ em relação à farinha de peixe (42\%). Estes resultados são próximos aos valores de 65 e $40 \%$ para a degradabilidade efetiva da proteína bruta do farelo de soja e farinha de peixe, respectivamente, apresentados no NRC (1996). 
A monensina reduziu a degradação da tripticase e farelo de soja, pela inibição da produção de amônia, e a própolis aumentou a degradação da farinha de peixe, pelo aumento da concentração de proteína solúvel em suspensão no meio. Estes resultados são difíceis de serem explicados, pois, no método tradicional de determinação das degradabilidades dos alimentos usando a técnica in situ, o que é medido é o desaparecimento da proteína através da solubilização da mesma e escape através dos poros dos saquinhos de náilon.

Entretanto, há necessidade de mais pesquisas para entender melhor este novo método de estudo do metabolismo de nitrogênio por microrganismos ruminais, uma vez que a determinação da degradação é mais completa, onde, além da determinação da solubilização da proteína, pode-se medir o acúmulo de peptídeos e síntese de amônia e proteína microbiana (Barbosa et al., 2001).

\section{Conclusões}

A monensina e a própolis foram eficientes em reduzir a produção de amônia de fontes de proteína de maior degradabilidade.

A própolis foi mais eficiente que a monensina em manter maiores concentrações de proteína solúvel no início das incubações, pela redução da atividade de desaminação.

Devido ao efeito in vitro da própolis sobre a atividade de fermentação, há necessidade de realização de pesquisas para verificar o efeito da mesma sobre a fermentação ruminal e sobre o desempenho animal.

\section{Literatura Citada}

BARBOSA, N.G.S.; LANA, R.P.; MÂNCIO, A.B. et al. Fermentação da proteína de seis alimentos por microrganismos ruminais, incubados puros ou com monensina ou Rumensin. Revista Brasileira de Zootecnia, v.30, p.1316-1323, 2001.

CHANEY, A.L.; MARBACH, E.P. Modified reagents for determination of urea and ammonia. Clinical Chemistry, v.8, p.130-132, 1962.

CHEN, G.; RUSSELL, J.B. More monensin-sensitive, ammoniaproducing bacteria from the rumen. Applied and Environmental Microbiology, v.55, p.1052-1057, 1989.

CUNHA, L.T. Efeito da acidez e de ionóforos na degradação de proteínas por microrganismos ruminais. Viçosa, MG: Universidade Federal de Viçosa, 1999. 68p. Dissertação (Mestrado em Zootecnia) - Universidade Federal de Viçosa, 1999.

GHISALBERTI, E.L. Própolis: a review. Bee World, v.60, p.59-84, 1979.

HINO, T.; RUSSELL, J.B. Relative contributions of ruminal bacteria and protozoa to the degradation of protein in vitro. Journal of Animal Science, v.64, p.261-270, 1986.
KRAUSE, D.O.; RUSSELL, J.B. An rRNA approach for assessing the role of obligate amino acid-fermenting bacteria in ruminal amino acid degradation. Applied and Environmental Microbiology, v.62, p815-821, 1996.

LOWRY, O.H.; ROSEBROUGH, N.J.; FARR, A.L. et al. Protein measurement with the Folin phenol reagent. Journal of Biological Chemistry, v.193, p.265-275, 1951.

NATIONAL RESEARCH COUNCIL - NRC. Nutrient requirements of beef cattle. 7.ed. Washington, DC: National Academy Press, 1996. 242p.

NOLAN, J.V.; NORTON, B.W.; LENG, R.A. Further studies of the dynamics of nitrogen metabolism in sheep. British Journal of Nutrition, v.35, p.127-147, 1976.

RUSSELL, J.B. Bacteria: Mechanisms of ionophore action in ruminal bacteria. In: 1996 SCIENTIFIC UPDATE ON RUMENSIN/TYLAN/MICOTIL FOR THE PROFESSIONAL FEEDLOT CONSULTANT, 1996, Indianapolis, IN.Proceedings...Indianapolis: Elanco animal Health, 1996. p.E1-E19.

RUSSELL, J.B.; O'CONNOR, J.D.; FOX, D.G. et al. A net carbohydrate and protein system for evaluating cattle diets. I. Ruminal fermentation. Journal of Animal Science, v.59, p.1329-1338, 1992.

RUSSELL, J.B.; MARTIN, S.A. Effects of various methane inhibitors on the fermentation of amino acids by mixed rumen microorganisms in vitro. Journal of Animal Science, v.59, p.1329-1338, 1984.

RUSSELL, J.B.; STROBEL, H.J. Mini-review: the effect of ionophores on ruminal fermentation. Applied and Environmental Microbiology, v.55, n.1, p.1-6, 1989.

RUSSELL, J.B.; STROBEL, H.J.; CHEN, G. The enrichment and isolation of a ruminal bacterium with a very high specific activity of ammonia production. Applied and Environmental Microbiology, v.54, p.872-877, 1988.

STATISTICAL ANALYSIS SYSTEM-SAS. SAS/STAT User's Guide. Release 6.12. Cary: 1996.

SATTER L.D.; SLYTER, L.L. Effect of ammonia concentration on rumen microbial protein production in vitro. British Journal of Nutrition, v.32, p.199-205, 1974.

SILVA, D.J. Análises de alimentos (métodos químicos e biológicos). 2.ed. Viçosa, MG: Universidade Federal de Viçosa, 1990. 24p.

STRADIOTTI Jr., D.; QUEIROZ, A.C.; LANA, R.P. et al. Ação da própolis sobre microrganismos ruminais e sobre alguns parâmetros de fermentação no rúmen. In: REUNIÃO ANUAL DA SOCIEDADE BRASILEIRA DE ZOOTECNIA, 38., 2001, Piracicaba. Anais...Piracicaba: Sociedade Brasileira de Zootecnia, 2001. p.942-944.

YANG, C.-M.J.; RUSSELL, J.B. Effect of monensin on the specific activity of ammonia production by ruminal bacteria and disappearance of amino nitrogen from the rumen.Applied and Environmental Microbiology, v.59, p.3250-3254, 1993.

YECK, R.G.; SMITH, L.W.; CALVARERT, C.C. Recovery of nutrients from animal wastes, an overview of existing options and potentials for use in feed. In: INTERNATIONAL SYMPOSIUM OF LIVESTOCK WASTES, 3., 1975, St. Joseph, MI. Proceedings... St. Joseph, MI: American Society of Agricultural Engineers, 1975. p.193-194. 